\title{
PEMBENTUKKAN KARAKTER PESERTA DIDIK MELALUI PEMANFAATAN LAGU ANAK-ANAK DI KELOMPOK BERMAIN FLAMBOYAN DESA KOTA BANGUN III KECAMATAN KOTA BANGUN KABUPATEN KUTAI KARTANEGARA PADA TAHUN AJARAN 2016/2017
}

\author{
Rawin \\ PG PAUD, FKIP, Universitas Widya Gama Mahakam Samarinda \\ ( rawin.hendrawanto@yahoo.com) \\ Mahkamah Brantasari \\ PG PAUD, FKIP, Universitas Widya Gama Mahakam Samarinda \\ (brantasari@gmail.com)
}

\begin{abstract}
Shaping child character is an important aspect during the process of early childhood development. One of learning method that encourage child character is by using songs for children to create fun learning atmosphere that gets rid of boredom frustration. As the consequence, the researcher conducted a classroom action research to shape better child character through the usage of songs for children. Moreover, the research was conducted in Flamboyan Playgroup in Desa Kota Bangun III Kecamatan Kota BangunKabupatenKutaiKartanegara.

In addition, to collect the data, the researcher employed teacher and students observation sheet and documentation. The research subjects were twenty five students. To analyze the data, the researcher applied descriptive analysis with qualitative approach.

The result of the research shows that students' character has improved after learning with child songs. Since, at the early cycle, students' character developed $25 \%$. Meanwhile, after implementing child songs, the character developed into $85 \%$, which met the research target. Moreover, the teacher felt easier to deliver moral value through songs since the students felt happy during learning.
\end{abstract}

Key words: child character, songs for children

\section{PENDAHULUAN}

\author{
Pendidikan merupakan faktor \\ utama dalam pembentukan pribadi \\ manusia. Sedangkan pribadi sangat \\ berperan dalam membentuk baik atau \\ buruknya tingkah laku manusia dalam \\ ukuran normatif. \\ Pada anak usia dini biasanya \\ karakternya masih berubah-ubah sesuai \\ dengan perkembangannya. Karakteristik \\ pada anak banyak yang berpendapat
}

bawaan sejak lahir ada pula yang berpendapat lingkunganlah yang membentuk perwatakan dari anak-anak. Ada juga pendapat yang mengatakan bahwa anak-anak adalah miniature orang dewasa dan adapula yang memandang anak sebagai individu yang berbeda. Montesori (dalam Hurlock, 1978) berpendapat bahwa pada usia 3-6 tahun merupakan periode dimana suatu fungsi tertentu perlu di rangsang, 
diarahkan sehingga tidak terhambat perkembangannya. Masa sensitif anak pada usia ini mencakup sensitif terhadap keteraturan lingkungan, mengekplorasi lingkungan dengan lidah dan tangan, sensitif untuk berjalan, sensitif terhadap objek-objek kecil dan detail, serta terhadap aspek-aspek yang membuat dia penasaran.

Pada era globalisasi ini manusia juga dihadapkan pada kemajuan informasi, teknologi, komunikasi dan lain sebagainya yang menjadikan kita sangat mudah bila ingin mengetahui sesuatu yang terjadi dibelahan bumi lainnya. Sehingga anak-anakpun bisa mendapatkan informasi dengan mudah, maka terdajilah krisis etika pada anakanak dan banyaknya anak - anak tidak memiliki karakter sopan santun yang dipicu oleh penggunaan dan pemanfaatan teknologi tidak sebagaimana mestinya.

Norma kesopanan sangat penting untuk diterapkan pada anak usia dini karena norma ini sangat erat kaitannya terhadap masyarakat. Sekali saja ada pelanggaran terhadap norma kesopanan, pelanggar akan mendapat sangsi dari masyarakat, semisal cemoohan. kesopanan merupakan tuntutan dalam hidup bersama yang harus dipenuhi supaya diterima secara sosial. Salah satu contoh kesopanan adalah tidak berkata kata kotor, kasar, sombong dan tidak menyela pembicaraan. Bahasa yang sopan menunjukkan karakter seseorang. Semakin halus bahasa seseorang semakin tinggi martabat orang tersebut. Oleh karena itu pentingnya di tanamkan norma kesopanan pada anak sejak usia dini khususnya dalam berkomunikasi dengan orang tua maupun masyarakat sekitar. Sopan santun pada anak usia dini sangat diperlukan karena pada masa ini anak sangat cepat menyerap hal - hal yang ada di sekitarnya baik ataupun buruk. Dengan dimasukkannya pendidikan karakter yang menyatu pada pemanfaatan lagu yang ada di Pendidikan Anak Usia Dini diharapkan anak -anak untuk lebih peduli dan memahami serta bertindak sesuai dengan nilai - nilai atau etika yang berlaku khususnya sikap sopan santun yang baik kepada orang yang lebih tua maupun masyarakat sekitarnya.

Dari penjelasan di atas memang pendidikan karakter sopan santun sangatlah penting bagi anak-anak usia dini karena anak-anak inilah yang merupakan kader penerus bangsa. UU No 202003 tentang Sisdiknas menyatakan bahwa Pendidikan Nasional berfungsi mengembangkan kemampuan dan membentuk watak serta peradaban bangsa yang bermartabat dalam rangka mencerdaskan kehidupan bangsa, bertujuan untuk berkembangnya potensi peserta didik agar menjadi manusia yang 
beriman dan bertakwa kepada Tuhan Yang Maha Esa, berakhlak mulia, sehat, berilmu, cakap, kreatif, mandiri, dan menjadi warga negara yang demokratis serta bertanggung jawab.

Untuk mendukung perwujudan cita-cita pembangunan karakter sebagaimana diamanatkan dalam Pancasila dan Pembukaan UUD 1945 serta mengatasi permasalahan kebangsaan saat ini, maka Pemerintah menjadikan pembangunan karakter sebagai salah satu program prioritas pembangunan nasional. Semangat itu secara implisit ditegaskan dalam Rencana Pembangunan Jangka Panjang Nasional (RPJPN) tahun 2005-2025, dimana pendidikan karakter ditempatkan sebagai landasan untuk mewujudkan visi pembangunan nasional, yaitu "Mewujudkan masyarakat berakhlak mulia, bermoral, beretika, berbudaya, dan beradab berdasarkan falsafah Pancasila". Anak-anak pada usia 3 tahun ke atas sudah mampu berinteraksi dan berkomunikasi dengan baik. Biasanya anak-anak pada masa ini sangat senang bicara dan menirukan. Pada usia 5-6 tahun anak-anak biasanya dimasukan oleh orang tua di Pendidikan Anak Usia Dini (Taman Kanak - Kanak, Kelompok Bermain, Tempat Penitipan Anak, Satuan Paud Sejenis, dll).

Sebelumnya peneliti melakukan pengamatan terhadap perkembangan anak terhadap permasalahan yang terjadi, khususnya di KB Flamboyan, Desa Kota Bangun III Kecamatan Kota Bangun Kabupaten Kutai Kartanegara pada kelompok B yang seluruhnya berjumlah 15 anak, dari jumlah tersebut hanya 2 anak (13,3\%) yang mau menjawab salam, mengucapkan kata terima kasih saat menerima pemberian, mengucapkan kata minta tolong ketika meminta bantuan dan 13 anak $(86,6 \%)$ yang belum mau menjawab salam, mengucapkan kata terima kasih saat menerima pemberiaan, mengucapkan kata minta tolong ketika meminta bantuan dan lain-lain.

Pendidikan Anak Usia Dini melalui seni musik adalah pendidikan yang terkait dengan pembelajaran menggunakan seni musik. Pembelajaran ini mencakup semua aspek pembelajaran, termasuk psikomotor (pengembangan kemampuan), kognitif (pemerolehan pengetahuan), dan afektif (pengembangan pribadi), termasuk apresiasi musik dan sensitivitasnya. Keberadaan pelmbelajaran melalui seni musik mulai dari pendidikan prasekolah sampai paska sekunder umum ditemukan di berbagai negara karena keterlibatan dalam musik dianggap sebagai komponen dasar budaya dan perilaku manusia. Musik, seperti bahasa, adalah pencapaian yang membedakan manusia dengan mahluk lain. 
Pendidikan yang menggunakan seni musik juga merupakan pendidikan yang dapat mengembangkan kepriadian anak secara langsung dan tidak langsung. Dengan belajar melalui seni musik anak akan banyak mendapatkan perkembangan kreatifitas, inovatif dan rasa estetik secara mendalam. Perkembangan yang dimaksud merupakan proses yang diperlukan anak didalam kehidupannya, baik secara langsung maupun tidak langsung. Secara langsung dapat dilihat dari perkembangan kognitif dan psikomotor mereka dalam melaksanakan aktifitas belajar untuk kemampuan sewaktu beraktifitas dan perkembangan anak secara tidak langsung juga akan dapat mereka rasakan dalam kehidupan sehari hari dalam berinteraksi pada lingkungan mereka yang dapat dilihat dari asfek afektifnya.

Disini dengan menggunakan media musik dan suara dalam berbagai cara yang kreatif, pendidik dapat membantu peserta didik mengembangakan rasa percaya diri, sejak awal sehingga nantinya sikap yang dikembangkan tersebut akan menjadi karakter tetap pada anak nantinya. Berbagai macam lagu anak-anak dapat digunakan dalam pembentukan karakter pada anak, melalui lirik dan melodi yang ada di setiap lagu, anak-anak akan lebih mudah menerima maksud serta nilai-nilai yang ada pada lagu tersebut. Dalam praktikanya musik lebih mengandalkan perasaan dan emosi, hal ini berhubungan dengan moral. Pembentukan karakter juga menekankan pada tumbuhnya moral yang tinggi pada peserta didik maka dapat dikatakan bahwa pendidikan seni musik selaras dengan upaya pembentukan karakter.

Berdasarkan uraian di atas, maka keadaan yang seperti ini tidak untuk di diamkan begitu saja, karena permasalahan yang terjadi tidak lepas dari kurangnya wawasan guru dalam memilih metode dan media pembelajaran yang tepat, oleh karena itu juga peneliti ingin melakukan tindakkan kelas di kelompok Bermain Flamboyan, dengan harapan dapat melakukan perbaikan dan dapat meningkatkan perkembangan karakter sopan santun anak menjadi lebih baik, salah satunya dengan menggunakan metode pembelajaran pengembangan karakter anak melalui lagu atau bernyanyi, dengan metode tersebut di harapkan kegiatan pembelajaran menjadi lebih bermakna dan menyenangkan serta tidak membosankan bagi anak.

\section{METODE PENELITIAN}

Desain Penelitian

Penelitian ini menggunakan metode penelitian tindakan kelas (PTK), dilaksanakan dalam bentuk proses 
pengkajian berdaur 2 tahap, yaitu : Tahap Perencanaan, Pelaksanaan, Pengamatan serta Refleksi. Model PTK menurut Suharsimi Arikunto dapat di lihat pada gambar bagan di bawah ini :

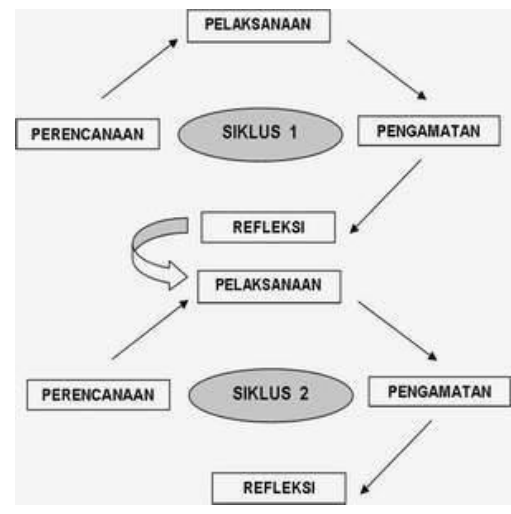

Gambar.1 Siklus Penelitian Tindakan

Model PTK yang di gunakan peneliti adalah model Penelitian dari Suharsimi Arikunto ( 2016:41), Model Penelitian Tindakan Kelas ( PTK ) dapat dikatakan penelitian eksperimen berulang atau eksperimen berkelanjutan, meskipun tidak selalu demikian. Dalam bagan 3.1 terlihat ada dua lingkaran yang dimulai dari perencanaan, kemudian pelaksanaan, pengamatan dan sesudah itu refleksi. Tahapan pelaksanaan tindakkan atau acting meliputi segala tindakan yang tertuang dalam rencana pelaksanaan pembelajaran RPPM dan RPPH dengan materi pengembangan karakter sopan santun pada anak usia dini. Dalam hal ini peniliti mengajar sesuai dengan RPPM dan RPPH yang telah di persiapkan. Tahap pengamatan atau observing meliputi pembuatan instrumen penelitian, pengumpulan data berupa nilai evaluasi siswa setelah mendapatkan tindakan, menganalisa data dan menyusun langkah - langkah perbaikan. Tahapan refleksi dilakukan melalui diskusi teman sejawat dan masukan dari para ahli penelitian tindakan kelas. Dalam penelitian ini dilakukan dua siklus, setiap siklus meliputi :

\section{Siklus I :}

1. Tahapan perencanaan dipilih pokok bahasan yang sesuai dengan waktu yang tersedia yakni teridiri dari 6 kali pertemuan, 3 pertemuan pada siklus I dan 3 pertemuan lagi pada siklus II. Untuk topik pembelajaran yaitu Pengembangan Karakter sopan santun melalui pemanfaatan lagu, di rencanakan RPPH untuk pokok bahasan tersebut secara rinci untuk setiap pertemuan. Disiapkan bahan dan media pembelajaran yang akan di gunakan serta dokumen yang lain.

2. Tahapan tindakan meliputi segala tindakan yang tertuang dalam rencana pelaksanaan pembelajaran RPPM dan RPPH dengan materi pembentukkan karakter sopan santun.

3. Tahapan pengamatan yaitu melakukan pengamatan terhadap proses pembelajaran dan respons 
kelas, serta siswa dengan memakai instrumen yang telah di siapkan berupa lembar observasi yang telah dirancang.

4. Tahapan refleksi adalah melakukan evaluasi untuk memperbaiki pembelajaran, dilakukan melalui diskusi teman sejawat dan masukan dari para ahli penelitian tindakkan kelas.

Siklus II :

1. Tahapan perencanaan adalah kembali merancang RPPH untuk bahasan lanjutan dengan perbaikan dan penyempurnaan tindakkan pembelajaran sesuai dengan masukkan hasil refleksi siklus ke-I. kembali disiapkan bahan dan media pembelajaran dan kembali merancang instrument.

2. Tahapan pelaksanaan adalah melaksanakan pembelajaran di sklus ke -II dengan topik lanjutan, pada siklus kedua ada perbaikan atau penyempurnaan pada siklu ke-I

3. Tahapan pengamatan adalah kembali melakukan pengumpulan data baik proses maupun hasil pembelajaran dengan metode yang baru dan menghimpun hasil pengamatan dan analisis hasilnya.
4. Tahapan refleksi memplajari hasil analisis pengamatan untuk bahan pembuatan laporan.

Tabel 1

Tahapan-tahapan Siklus 1 dan siklus II

\begin{tabular}{|l|l|}
\hline NO & URAIAN KEGIATAN \\
\hline Siklus 1 \\
\hline 1 & $\begin{array}{l}\text { Memberi dan menjawab salam saat bertemu } \\
\text { dengan seseorang }\end{array}$ \\
\hline 2 & Mengucapkan kata maaf dan memberi maaf \\
\hline 3 & $\begin{array}{l}\text { Mengucapkan kata tolong saat memerlukan } \\
\text { bantuan dari orang lain dan mengucapkan } \\
\text { terima kasih saat menenrima bantuan }\end{array}$ \\
\hline Siklus II \\
\hline 1 & $\begin{array}{l}\text { Mengucapkan kata permisi saat melewati di } \\
\text { hadapan orang }\end{array}$ \\
\hline 2 & $\begin{array}{l}\text { Meminta ijin ketika menginginkan milik } \\
\text { orang lain. }\end{array}$ \\
\hline 3 & $\begin{array}{l}\text { Berbicara tidak dengan berteriak dan tidak } \\
\text { mengucapkan kata kata kasar atau kotor }\end{array}$ \\
\hline
\end{tabular}

\section{Subjek Penelitian}

Subjek penelitian Subjek Penelitian Tindakkan Kelas ( PTK ) yaitu siswa siswi Kelompok Bermain Flamboyan, Desa Kota Bangun III Kabupaten Kutai Kartanegara, dengan menerapkan metode pemanfaatan lagu dalam pembentukan karakter anak usia dini, yang jumlah siswanya 15 siswa.

\section{Instrumen Penelitian}

1. Observasi

Menurut Suharsimi Arikunto .(2016:221) Pengertian observasi adalah kegiatan pengamatan ( pengambilan data ) untuk memotret seberapa jauh efektif tindakan telah mencapai sasaran. Pada langkah ini peneliti menguraikan jenis jenis data yang dikumpulkan.

2. Skala penilaian Deskripsi

Menurut Suharsimi Arikunto .(2016:227) Pengertian skala penilaianDeskripsi adalah panduan dari 
pengamatan kuantitatif dan pengamatan kualitatif yang dijabarkan dalam bentuk skala. Adapun dalam penelitian ini skala deskripsi digunakan untuk menilai lembar observasi dengan skala kriteria : Belum Muncul (BM), Mulai Muncul (MM), Mulai Berkembang (MB), Berkembang Sesuai Harapan (BSH), Berkembang Sangat Baik (BSB). Kriteria selalu dengan bobot, Nilai : 1, Belum Muncul (BM): 2, Mulai Muncul (MM): 3, Mulai Berkembang (MB) : 4, Berkembang Sesuai Harapan (BSH), di sini peneliti telah menentukan indikator dan sub indikator berdasarkan variable yang akan di teliti dengan mengunakan skala.

\section{Tehnik Pengumpulan Data}

Tehnik pengumpulan data pada penelitian ini dapat di uraikan sebagai berikut :

1. Data tentang situasi pembelajaran pada saat dilaksanakan pembelajaran dikumpulkan dengan menggunakan lembar pengamat observasi pada setiap siklus.

2. Dokumentasi aktivitas siswa (foto menggunakan kamera HP) diambil pada setiap siklus.

Pengumpulan data ini adalah cara untuk memperoleh penjelasan atau keterangan dasar dalam penelitian yang berguna untuk bahan pemecahanmmasalah yang ditemukan dalam penelitian. Untuk itu diperlukan tehnik pengumpulan data yang tepat agar penelitian mencapai tujuan yang diinginkan. Pengambilan data dilakukan dengan cara :

1. Pengamatan atau observasi dalam rangka pengumpulan data dengan mengamati perkembangan karakter anak.

2. Skala penilaian deskripsi, tehnik yang digunakan untuk memperoleh data tentang perkembangan karakter anak dengan menggunakan media lagu.

3. Dokumentasi yaitu mendokumentasikan segala kegiatan selama penelitian.

4. Dokumentasi berupa foto-foto kegiatan proses belajar.

\section{Tehnik Analisis Data}

Analisi data adalah suatu cara untuk menganalisis data selama peniliti mengadakan penelitian. Penelitian ini termasuk penelitian kuantitatif dan kualitatif. Secara kuantitatif data yang terkumpul dianalisa secara deskriptif presentase. Tingkat perubahan yang terjadi diukur dengan persen. Jumlah anak yang mampu mencapai indikator keberhasilan dibagi jumlah seluruh anak yang diteliti dikalikan seratus persen, maka diketahui presentase dari tindakan. Hal tersebut untuk mengetahui nilai ketuntasan rata - rata kelas secara keseluruhan dengan rumus :

$$
\mathrm{P}=\frac{\mathrm{N}}{\mathrm{A}} \times 100 \%
$$




$$
\begin{array}{ll}
\mathrm{P} & =\text { Presentase tingkat ketuntasan } \\
\mathrm{N} & =\text { Jumlah Siswa yang mendapat } \\
& \text { nilai di atas KKM tuntas } \\
\mathrm{A} & =\text { Jumlah anak }
\end{array}
$$$$
\text { Indikator keberhasilan dalam }
$$
penelitian ini apabila minimal 80\% (12 anak) dari jumlah anak didik kriteria ketuntasan yang telah ditentukan oleh peneliti. Sedangkan secara kualitatif menerangkan aktifitas anak dan guru yang diperoleh melalui observasi, dan unjuk kerja selama penelitian berlangsung.

Untuk mendapatkan nilai rata-rata ketuntasan kelas secara keseluruhan maka perlu di buat nilai-nilai ketuntasan setiap anak terlebih dahulu melalui lembar pengamatan anak setiap hari selama beberapa kali pertemuan, dengan rumus sebagai berikut :

\section{Nilai Individu $\times 100 \%$ \\ Skor Maksimal \\ Indikator keberhasilan individu} setiap anak dalam penelitian ini apabila minimal $80 \%$ dari jumlah kriteria ketuntasan yang telah ditentukan oleh peneliti. Anak yang telah memperoleh angka 4 berarti telah memenuhi kriteria tuntas sempurna, sedangkan anak yang mampu mencapai nilai 3 berarti anak yang telah memenuhi kriteria tuntas, kemudian anak yang memperoleh nilai 2 dan 1 berarti anak tersebut belum mencapai kriteria tuntas dan aspek indikator yang diharapkan belum dapat di capai anak.

\section{PEMBAHASAN}

\section{Hasil Penelitian setelah diberikan tindakkan pada Siklus 1}

\section{a. Deskriptif Data Pelaksanaan}

Tindakaan Siklus 1 :

Deskripsi pada metode ini dengan menggunakan lagu dalam upaya mengembangkan karakter anak pada sikulu I, berdasarkan pelaksanaan siklus pertama dari 15 anak, ada yang sudah mencapai kemampuan maksimal walau hanya beberapa anak saja, masih ada beberapa anak yang belum mendapat peningkatan dalam pembentukkan karakternya. Tingkat pencapaian yang di peroleh anak dalam meningkatkan karakter sopan santun dengan metode lagu sebanyak $75 \%$ ini adalah perkembangan yang baik dari sebelum di lakukan tindakkan. Walaupun sudah menunjukkan perubahan yang meningkat namun masih dibutuhkan tindakkan lagi pada siklus II supaya mencapai indikator keberhasilan. Bebrapa hal yang harus diperhatikan guru dalam perbaikan pada sikulus I yaitu :

a. Perlunya penambahan media belajar seperti media gambar .

b. Penguasaan dalam menyajikan syair lagu 
c. Pengelolaan kelas agar metode yang di gunakan tidak membuat anak - anak jenuh.

d. Aktivitas anak didik dalam meningkatkan pembentukkan karakter.

Hasil yang didapat data di atas dapat diketahui bahwa anak didik yang memberi danmejawab salam saat bertemu dengan seseorang $82 \%$, Mengucapkan kata maaf dan memberi maaf $73 \%$, Mengucapkan kata tolong saat memerlukan bantuan dari orang lain dan mengucapkan terima kasih saat menerima bantuan $80 \%$, Mengucapkan kata permisi saat melewati di hadapan orang $76 \%$, Meminta ijin ketika menginginkan milik orang lain.78\%, Berbicara tidak dengan berteriak dan tidak mengucapkan kata - kata kasar atau kotor $78 \%$.berdasarkan presentase diatas peneliti menunjukkan bahwa tingkat pencapaian masih belum tuntas masih banyak aspek yang harus di tingkatkan pencapaiannya atas hasil yang dicapai, kemudian peneliti mengadakan penelitian tindakkan kelas kembali pada siklus dua.

\section{Hasil Penelitian Setelah diberikan tindakkan pada siklus II}

Hasil analisis pelaksanaan pembelajaran dengan menggunakan metode lagu pada siklus II, secara umum telah menunjukkan perubahan yang cukup memuaskan, dimana dalam melaksanakan pembelajaran semakin mantap dan luwes dengan kekurangan kekurangan kecil dianataranya kurang control waktu dan belum memberikan tindak lanjut.

Dari 15 anak didik yang mengikuti kegiatan tersebut diatas sudah melaksanakannya dengan baik, ada sekitar $85 \%$ yaitu sebanyak 12 anak, dengan demikian hasil pelaksanaan tindakkan kelas pada siklus II sudah lebih baik dari siklus I. Pada Proses pembelajaran siklus II dengan kegiatan bernyanyi upaya meningkatkan perkembangan karakter sopan santun pada anak di Kelompok Bermain Flamboyan Desa Kota Bangun 3 dilakukan selama 2 siklus yang mana hasil penelitian menunjukkan adanya perkembangan sampai dengan $94 \%$, ketika peneliti memakai metode pembentukkan karakter sopan santun melalui pemanfaatan lagu.

\section{Pembahasan Hasil Penelitian}

Meningkatkan pembentukkan karakter sopan santun pada anak melalui pemanfaat lagu di Kelompok Bermain Flamboyan Desa Kota Bangun 3.

Berdasarkan nilai perkembangan anak didik semester awal dan sebelum diberikan tindakkan, diketahui sikap sopan santun anak didik sangat rendah, tingkat perkembangan hanya mencapai sekitar $53 \%$, yaitu sekitar 8 anak saja yang memahami sikap sopan santun 
cukup baik, melihat kondisi demikian maka peneliti memberi pelajaran dengan menggunakan pemanfaatan lagu, maka terjadi peningkatan secara bertahap dari siklus pertama terjadi peningkatan sekitar $73 \%$, yaitu sekitar 12 anak, kemudian dilakukan penelitian ulang pada siklus kedua terjadi peningkatan sekitar $94 \%$, yaitu sekitar 15 anak.

Maka dari itu pembelajaran dengan memanfaatkan lagu untuk pembentukkan karate sopan santun anak didik sangat berhasil, anak tidak merasa jenuh dan sangat antusias dalam meningkatkan pembelajaran.

\section{PENUTUP}

\section{Kesimpulan}

Berdasarkan hasil penelitian
tindakan kelas dengan judul “
PembentukkanKarakter Sopan Santun Peserta Didik Melaui Pemanfaatan Lagu Anak-anak DiKelompok Bermain Flamboyan Desa Kota Bangun III Kecamatan KotaBangun" dapat di simpulkan bahwa penggunaan metode pembelajaranmemlalui lagu anak dapat meningkatkan karakter sopan santun peserta didikKelompok Bermain Flamboyan Desa Kota Bangun III pada tahun 2016 / 2017.Penelitian tindakkan kelas ini telah dilaksanakan melalui dua siklus. Hal initelah menghasilkan kesimpulan senagai berikut:

1. Perkembangan aspek memberi dan menjawab salam saat bertemuseseorang, sebelum di berikan tindakan hanya $53 \%$ yaitu sebanyak 8 anaksaja, dengan diadakan metode pembelajaran melalui lagu anak mengalamipeningkatan, dimana peningkatan tersebut terjadi secara bertahap padasiklus pertama terjadi peningkatan sekitar 73\%, selanjutnya pada siklus kedua terjadi peningkatan sekitar $94 \%$ atau sebanyak 15 anak.

2. Dari hasil akhir penelitian mengucapkan kata maaf dan memberi maaf ada $86 \%$ yaitu 15 anak, terbiasa mengucapkan kata maaf dan memberi maaf, dimana sebelumnya hanya mencapai $73 \%$ yaitu 9 anak saja. Mengucapkan kata tolong saat memerlukan bantuan dari orang lain dan mengucapkan terima kasih saat menerima bantuan sebnayak $87 \%$ yaitu 15 anak, Mengucapkan kata permisi saat melewati di hadapan orang $86 \%$ yaitu sebanyak 15 anak, Meminta ijin ketika menginginkan milik orang lain $93 \%$ atau sebanyak 15 anak, berbicara tidak berteriak dan tidak mengucapkan kata kata kasar/ kotor $90 \%$ yaitu sebanyak 15 anak.

3. Anak-anak Kelompok Bermain Flamboyan Desa Kota Bangun III sudah lebih mudah untuk 
melakukan hal-hal yang bernilai karakter sopan santun, berdasarkan pengamatan siklus satu dan siklus dua bahwa metode pembentukkan karakter sopan santun melalui pemanfaatan lagu anak di Kelompok Bermain Flamboyan Desa Kota Bangun III.

\section{Saran - Saran}

\section{Bagi Pendidik}

a. Sebagai pendidik harus mampu merencanakan, melaksanakan dan mengevaluasi program pembelajaran. Ketiga kegiatan tersebut sangat penting dan sangat erat hubungannya. Perencanaan pembelajaran didasarkan pada pelaksanaan dan evaluasi sebelumnya, pelaksanaan program didasarkan pada perencanaaan dan evaluasi. Evaluasi dilakukan berdasarkan perencanaan dan pelaksaan program, evaluasi berguna untuk menentukan langkah pembelajaran berikutnya, utamanya jika ditemukan masalah maka akan segera bisa melakukan tindakkan.

b. Guru di dalam melakukan kegiatan hendaknya memilih metode dan media yang sesuai dengan perkembangan anak agar menarik dan meyenangkan, sehingga tujuan pembelajaran dapat dicapai dengan baik. c. Metode pemanfaatan lagu anak uttuk pembentukkan karakter sopan santun anak di Kelompok Bermain Flamboyan telah terbukti dapat digunakan untuk mencapai tujuan.

d. Bagi pendidik diharapkan dapat mengembangkan media pembelajaran sendiri yang sesuai dengan kebutuhan perkembangan anak, utamanya untuk mencari dan menemukan metode - metode baru yang diseduaikan dengan tujuan pendidikan.

2. Bagi Orangtua

a. Agar orangtua mengetahui tingkat perkembangan anak dalam mengembangkan karakter sopan santun yang di miliki anak.

b. Agar orang tua dapat memberikan tindakan yang sama ketika anak berada di rumah bersama orangtuanya.

\section{DAFTAR PUSTAKA}
Asep Herry Hervawan. 2008. Pengembangan Kurikulum dan Pembelajaran (Online). Jakarta: Universitas Terbuka. (http://akhmadsudrajat.wordpress.co m, di akses 20 Mei 2017)

Ahmad Susanto. (2011) Perkembangan Anak Usia Dini pengantar dalam Berbagai Aspenya (Online). Jakarta: Kencana Perdana Media Group. (http://digilib.unisby.ac.id, di akses 14 Mei 2017) 
Jurnal Warna : Jurnal Pendidikan Dan Pembelajaran Anak Usia dini. Maret 2018. Vol 03. No. 01

Departemen Pendidikan Nasional. 2010.

Kebijakan Nasional Pembangunan Karakter Bangsa. Jakarta: Depdiknas.

E.Mulyasa. 2009. Praktik Penelitian Tindakan Kelas,(Online) Bandung : PT. Remaja Rosdakarya. (http://eprints.walisongo.ac.id/, di akses 13 Mei 2017)

Mulya Achdami. 2006. PAUD Investasi Masa Depan Bangsa. Jakarta : Direktorat

Jendral Pendidikan Luar Sekolah Departemen Pendidikan Nasional.

Munif Chatib. 2012. Orangtuanya Manusia. Bandung: PT. Mizan Pustaka.

Munif Chatib. 2012. Sekolah Anak- Anak Juara. Bandung : PT. Mizan Pustaka.

R.I. Sarumpaet. 2001. Rahasia Mendidik Anak. Bandung : Indonesia Publishing House.

Suharsimi Arikunto ,2016. Penelitian Tindakkan Kelas Edisi Revisi Jakarta : PT. Bumi Aksara. 